\title{
Enteroparasites prevalence among daycare and elementary school children of municipal schools, Rolândia, PR, Brazil
}

\author{
Prevalência de enteroparasitoses em crianças de creches e alunos da \\ rede municipal de ensino de Rolândia, Paraná
}

Nilson Giraldi ${ }^{1}$, Odilon Vidotto ${ }^{2}$, Italmar Teodorico Navarro² and João Luis Garcia ${ }^{1}$

\begin{abstract}
Coproparasitological analyses were performed on 191 daycare children and 434 elementary school children from urban and rural areas in Rolândia, Parana State, Brazil. The overall prevalence of enteroparasites was $15.2 \%$ for daycare children and $52.5 \%$ for elementary school children. Risk factors are discussed.
\end{abstract}

Key-words: Parasitic infection. Epidemiology. Prevalence. School children. Daycare. Brazil.

Resumo Exames coproparasitológicos realizados em 191 crianças de creches e em 434 alunos da primeira à quarta série das áreas urbana e rural da rede municipal de Rolândia, $P R$, evidenciaram enteroparasitas em prevalência de 15,2\% nas creches e de 52,5\% entre os escolares. Fatores de risco são discutidos.

Palavras-chaves: Infestação parasitária. Epidemiologia. Escolares. Creches. Brasil.

From March to September of 1998,191 children from 1 to 6 years old from 4 daycare schools of urban areas of Rolândia, were submitted to coproparasitolgic tests to evaluate the prevalence of enteroparasites. Furthermore, to evaluate the prevalence of the enteroparasitosis among children up 6 years old, there was utilized a sample of the 2589 students from urban and rural elementary schools (2300 urban and 289 from rural schools). From October to December of 1998 , coproparasitologic tests were performed in 276 students from urban area and 158 rural. The magnitude of the sample from each school was dictated by soft Epi-Info 6 . Students were chosen arbitrarily.

Parents and students answered a questionnaire to reveal epidemiological aspects of enteroparasitosis, such as the habit of washing hands before meals, the habit of ingesting crude milk, meat or vegetables, having a garden at home, contact with dogs and cats, keeping animals at home, water supply, fecal disposal and habit of walking barefoot. Fecal samples were brought from home, in appropriate plastic bowls and properly identified. They were immediately remitted to the laboratory, kepton at refrigerator at $4^{\circ} \mathrm{C}$ until processing as outlined by Faust et $\mathrm{al}{ }^{9}$ and Hoffman et $\mathrm{al}{ }^{4}$ methods.
The odd's ratio (OR) was estimated to establish forces of association between studied variables and the significance determined when $95 \%$ of confidance interval did not include the 1 . The association analysis between the groups were tested by Chi-square test $\left(x^{2}\right)$, with statistical significance determined when $p<0.05$.

Among daycare children it was observed that 29 (15.2\%) had positive results by coproparasitologic test, by unique or mixed infections (Table1). A. lumbricoides was the most prevalent, occuring in $13(6.8 \%)$ children, followed by Giardia lamblia in eight (4.2\%), Enterobius vermicularis in five $(2.6 \%)$, Ancylostomatidae in two $(1 \%)$ and Strongyloides in one (0.5\%), as revealed in Table 2.

One hundred and fifty two $(55.1 \%)$ urban area students and $76(48.1 \%)$ rural area students were positive. There was no significant difference in the presence of endoparasites between students of urban and rural areas $\left(x^{2}=1.96 p=0.16\right.$, Table 1$)$. This similarity may be explained, with regard to the studied area, by the rural origin of many families. Even urban areas are under a strong rural influence, as well as migrant farm workers which can comprise part of the families of many urban students. The prevalence in urban areas is in accordance with Ferreira et $\mathrm{al}^{3}$ and Dórea et

\footnotetext{
1. Departamento de Medicina Veterinária Preventiva e Saúde Animal da Faculdade de Medicina da Universidade de São Paulo, São Paulo, SP.2. Departamento de Medicina Veterinária.e Preventiva da Universidade Estadual de Londrina, PR.

Address To: Dr. Nilson Giraldi, Rua Manoel Carreira Bernardino, 793, 86600-000 Rolândia, PR, Brazil.

e-mail:ngiraldi@yahoo.com.br

Recebido para publicação em 3/1/2000.
} 
Table 1 - Coproparasitologic results in daycare school children and elementary school students in Rolândia, Parana State, Brazil, 1998.

\begin{tabular}{|c|c|c|c|c|c|c|c|}
\hline \multirow{3}{*}{ Origin } & \multicolumn{4}{|c|}{ Coproparasitologic } & & & \multirow{3}{*}{ Statistic analysis } \\
\hline & \multicolumn{2}{|c|}{ positive* } & \multicolumn{2}{|c|}{ negative } & \multicolumn{2}{|c|}{ Total } & \\
\hline & $\mathrm{n}$ & $\%$ & $\mathrm{n}$ & $\%$ & $\mathrm{n}$ & $\%$ & \\
\hline Daycare & 29 & 15.2 & 162 & 84.8 & 191 & 100.0 & $\left(x^{2}=76.42 \quad p<0.01\right)$ \\
\hline \multicolumn{8}{|l|}{ Students } \\
\hline Urban areas & 152 & 55.1 & 124 & 44.9 & 276 & 63.6 & \\
\hline Rural areas & 76 & 48.1 & 82 & 51.9 & 158 & 36.4 & $\left(x^{2}=1.96 p=0.16\right)$ \\
\hline Total & 228 & 52.5 & 206 & 47.5 & 434 & & \\
\hline
\end{tabular}

* positive results include unique and mixed infections.

$\mathrm{al}^{1}$, in São Paulo, SP and Botucatu, SP. Although, Kobayashi et $\mathrm{al}^{5}$ reported an index of $70 \%$ in 222 habitants of rural areas in Holambra, SP, working with all ages of individuals.

Among students, there was a higher prevalence of protozoa than nematodes. G. lamblia occurred in 106 (38.6\%) urban students and $43(26.9 \%)$ rural ones. These findings are similar with previous data from São Jerômino da Serra, PR, in the same region ${ }^{7}$ Entamoeba histolitica occurred in two $(0.7 \%)$ samples from urban areas and in six (3.7\%) children of rural areas. In urban areas, Endolimax nana and Entamoeba coli exhibited the same prevalence, being identified in 37 (13.3\%) student fecal samples. In rural areas, E. nana occurred in $13(8.1 \%)$ and $E$. coli in $16(10 \%)$ samples. Hymenolepis nana was observed in 10 (3.8\%) urban students and in one $(0.1 \%)$ rural. Despite the fact that urban students receive exclusively treated water, it can be noted a high prevalence of hydro-transmission parasites, as is the case of protozoans. On other hand, feces disposal in the urban area studied is provided mostly by domestic systems. These results suggest that water treatment is not a protection factor with regard to these parasites.

For nematodes, of 276 students from urban areas, A. lumbricoides was demonstrated in 17 (6.1\%), Ancylostoma spp in 12 (4.3\%), Enterobius vermicularis and Trichuris trichuiura in two samples $(0.7 \%)$ and Strongyloides stercoralis in one $(0.4 \%)$ student.

In rural areas, of 158 students, $A$. lumbricoides was observed in two (1.2\%), Ancylostoma spp in seven $(4.4 \%)$ and $E$. vermicularis and $T$. trichiura occurred in one $(0.1 \%)$ child (Table 2$)$. These results were very similar to those of Marzochi \& Cavalheiro ${ }^{8}$, when performed on children ages 5-9 and 10-14, prevalences for G. lamblia of 29 and $12 \%$ were obtained, respectively.

Table 2 - Occurence of enteroparasites by coproparasitologic tests in daycare children and elementary school students, by urban or rural area in Rolândia, Parana State, Brazil, 1998.

\begin{tabular}{|c|c|c|c|c|c|c|}
\hline \multirow[b]{3}{*}{ Parasite } & \multicolumn{6}{|c|}{ Coproparasitologic } \\
\hline & \multicolumn{2}{|c|}{ daycare } & \multicolumn{2}{|c|}{ urban area } & \multicolumn{2}{|c|}{ rural area } \\
\hline & $\mathrm{n}$ & $\%$ & $\mathrm{n}$ & $\%$ & $\mathrm{n}$ & $\%$ \\
\hline Giardia lamblia & 8 & 4.2 & 106 & 38.6 & 43 & 26.9 \\
\hline Endolimax nana & 0 & 0.0 & 37 & 13.3 & 13 & 8.1 \\
\hline Entamoeba coli & 0 & 0.0 & 37 & 13.3 & 16 & 10.0 \\
\hline Ascaris lumbricoides & 13 & 6.8 & 17 & 6.1 & 2 & 1.25 \\
\hline Ancylostoma sp & 2 & 1.0 & 12 & 4.3 & 7 & 4.4 \\
\hline Enterobius vermicularis & 5 & 2.6 & 10 & 3.8 & 5 & 3.1 \\
\hline Hyminolepis nana & 0 & 0.0 & 10 & 3.8 & 1 & 0.1 \\
\hline Trichuris trichiura & 0 & 0.0 & 2 & 0.7 & 1 & 0.1 \\
\hline Entamoeba histolitica & 0 & 0.0 & 2 & 0.7 & 6 & 3.7 \\
\hline Strongyloides stercoralis & 1 & 0.5 & 1 & 0.4 & 0 & 0.0 \\
\hline
\end{tabular}

Of 113 boys from urban areas 63 (55.8\%) had positive corproparasitological tests. Among 163 girls, $89(54.6 \%)$ presented the same result. In rural areas, $39(52.7 \%)$ boys and 37 (44\%) girls. There was no difference in verminosis distribution between sexes in both areas $\left(x^{2}=0,04 p=0,85\right.$ in urban areas and $x^{2}=1.18 p=0.27$ in rural). Dórea et al $^{1}$ found a higher prevalence in boys and suggest that, at this age, boys have more contact with soil when playing and a less frequent use of shoes than girls.

In students, with regard to age, there was no measurable significant difference $\left(x^{2}=5.80 p=0,06\right.$ in urban areas and $x^{2}=2.56 p=0.27$ in rural Table 3 ).

The habit of washing hands before meals constitutes a protective factor against verminosis in rural areas $\left(\mathrm{OR}=0.350 .13<\mathrm{OR}<0.93 \mathrm{x}^{2}=5.57 \mathrm{p}=0.01\right.$ Table 4), in accordance with other studies ${ }^{16}$. 
Table 3 - Association between coproparasitologic results and age in elementary school students from Rolândia, Parana State, Brazil, 1998.

\begin{tabular}{|c|c|c|c|c|c|c|c|c|c|c|c|c|}
\hline \multirow{4}{*}{ Age groups } & \multicolumn{12}{|c|}{ Coproparasitology } \\
\hline & \multicolumn{6}{|c|}{ urban area } & \multicolumn{6}{|c|}{ rural area } \\
\hline & \multicolumn{2}{|c|}{ positive } & \multicolumn{2}{|c|}{ negative } & \multicolumn{2}{|c|}{ total } & \multicolumn{2}{|c|}{ positive } & \multicolumn{2}{|c|}{ negative } & \multicolumn{2}{|c|}{ total } \\
\hline & $\mathrm{n}$ & $\%$ & $\mathrm{n}$ & $\%$ & $n$ & $\%$ & $\mathrm{n}$ & $\%$ & $\mathrm{n}$ & $\%$ & $\mathrm{n}$ & $\%$ \\
\hline 6 a 7 & 48 & 64.0 & 27 & 36.0 & 75 & 27.2 & 16 & 47.1 & 18 & 52.9 & 34 & 21.5 \\
\hline 8 a 9 & 54 & 47.0 & 61 & 53.0 & 115 & 41.6 & 28 & 41.8 & 39 & 58.2 & 67 & 42.4 \\
\hline 310 & 50 & 58.2 & 36 & 41.8 & 86 & 31.2 & 32 & 56.1 & 25 & 43.9 & 57 & 36.1 \\
\hline Total & 152 & 55.1 & 124 & 44.9 & 276 & 100.0 & 76 & 48.1 & 82 & 51.9 & 158 & 100.0 \\
\hline
\end{tabular}

Table 4 - Association between the habit of washing hands before meals and coproparasitologic findings in students from rural schools, Rolândia, Parana State, Brazil, 1998.

\begin{tabular}{lccccccc}
\hline \multirow{2}{*}{ Washing hands habit } & \multicolumn{7}{c}{ Coproparasitologic } \\
\cline { 2 - 8 } & \multicolumn{2}{c}{ positive } & & \multicolumn{2}{c}{ negative } & & \multicolumn{2}{c}{ total } \\
\cline { 2 - 8 } & $\mathrm{n}$ & $\%$ & & $\mathrm{n}$ & $\%$ & $\mathrm{n}$ & $\%$ \\
\hline Present & 58 & 43.9 & 74 & 56.1 & 132 & 83.5 \\
Absent & 18 & 69.2 & 8 & 30.8 & 26 & 16.5 \\
\hline Total & 76 & 48.1 & 82 & 51.9 & 158 & 100.0 \\
\hline
\end{tabular}

OR=0.35 $\left(0.13<\right.$ OR $\left.<0.93 x^{2}=5.57 \quad p=0.01\right)$

In this present study in both urban and rural areas, other evaluated factors such as the habit of eating raw vegetables, having a garden, keeping animals at home, water supply, fecal disposal, and habit of walking barefoot did not influence coproparasitological results.

The data relating to nursery school are in accordance with Ferreira et $\mathrm{al}^{3}$ who also observed a higher prevalence of ascaridiasis in children less than 6 years old, in São Paulo, SP.

The difference in the occurrence of parasites between school children and daycare children $\left(x^{2}=76.42 p<0.01\right.$ Table 1) suggests that contact with the soil is one of the most important transmission sources for children less than 6 years old, whereas water and food contamination is most significant in ages above 6 years old.

\section{REFERENCES}

1. Dórea RCC, Salata E, Padovani CR, Anjos GL. Control of parasitic infections among school children in the peri-urban area of Botucatu, São Paulo, Brazil. Revista da Sociedade Brasileira de Medicina Tropical 29: 425-430, 1996.

2. Gross R, Schell B, Molina MCB, Leão MAC, Strack U. The impact of improvement of water supply and sanitation facilities on diarrhea and intestinal parasites: a brazilian experience with children in two low-income urban communities. Revista de Saúde Publica 23:214-220, 1989.

3. Ferreira CS, Ferreira MU, Nogueira MR. The prevalence of infection by intestinal parasites in an urban slum in São Paulo, Brazil. Journal of Tropical Medicine and Hygiene 97:121-127, 1994.

4. Hoffman WA, Pons JA, Janer JL. The sedimentation-concentration method in schistosomiasis mansoni Puerto Rico. Journal of Public Health 9p. 283-291, 1934.

5 Kobayashi J, Hasegawa H, Forli AA, Nishimura NF, Yamanaka A, Shimbukuro T, Sato Y. Prevalence of intestinal paarasitic infection in five farms in Holambra, São Paulo, Brazil. Revista do Instituto de Medicina Tropical de São Paulo 37:13-18, 1995.

6. Mamprim MILL, Moretti IG. Incidência de parasitoses intestinais em escolares na região de Londrina. Semina Ciências Biológicas 19(supl):27, 1998.

7. Matida CR, Rosa GO, Conchon-Costa I et al. Levantamento de enteroparasitoses em crianças de 0 a 15 anos em São Jerônimo da Serra - PR - Resultados preliminares. Semina Ciências Biológicas 19(supl):25, 1998.

8. Marzochi MCA, Carvalheiro JR. Estudos dos fatores envolvidos na disseminação dos enteroparasitas. Revista do Instituto de Medicina Tropical de São Paulo 20: 31-35, 1978.

9. Odrom V, Miller MJ, Peres C, Sawitz W, Thomen LF, Tobie J, Walker JH. A critical study of clinical laboratory techniques for the diagnosis of protozoan, cysts and helminth eggs in feces. American Journal of Tropical Medicine 18: 169-183, 1938. 